\title{
Seasonal Variations of Water Quality Parameters and Algal Flora of Tundzha (Tunca) River (Edirne, Turkey)
}

\author{
Burak Öterler ${ }^{*}$, Timur Kirgiz ${ }^{1}$, Meriç Albay ${ }^{2}$ \\ ${ }^{1}$ Trakya Üniversitesi, Fen Fakütesi, Biyoloji Bölümü, Edirne, Turkey \\ ${ }^{2}$ ìstanbul Üniversitesi, Su Ürünleri Fakültesi, Ordu Caddesi, İstanbul, Turkey \\ Email: burakoterler@hotmail.com, burakoterler@trakya.edu.tr
}

Received 25 July 2014; revised 26 August 2014; accepted 5 September 2014

Copyright (C) 2014 by authors and Scientific Research Publishing Inc.

This work is licensed under the Creative Commons Attribution International License (CC BY). http://creativecommons.org/licenses/by/4.0/

c) (i) Open Access

\begin{abstract}
In this study which was performed in order to determine the seasonal variations of water quality parameters and algal flora of Tundzha River, samplings were made monthly from 5 different stations along the river. A total of 138 taxa from Chlorophyceae (65 taxa), Bacillariophyceae (46 taxa), Euglenophyta (13 taxa) and Cyanophyta and Charophyta (7 taxa) were found to represent the algal flora of the river. Diatoms were recorded to be the dominant group throughout the year in terms of biovolume. Station I was the richest station during the whole study in terms of species diversity and composition. The maximum abundance of phytoplanktonic community within this station was $3,459,313$ cells $\cdot \mathrm{L}^{-1}$, and Station IV was found to be richest station in terms of biovolume, with $2028.8 \mu \mathrm{g} \cdot \mathrm{L}^{-1}$. The water quality of the river was found to be close to the $2 \mathrm{nd}$ and 3rd quality levels. 2nd and 3rd, and 1st and 3rd stations were found to be most similar to each other in terms of floristic compositions biovolume, respectively.
\end{abstract}

\section{Keywords}

Tundzha River, Physico-Chemical Parameters, Phytoplankton, Algae Composition, Biomass

\section{Introduction}

From the beginning of plankton research [1], the main focus of interest has been given on lentic waters, especially large lakes. The ecological and functional roles of potamoplanktons in fluvial ecosystems were first described in the early studies [2]-[4] whose results have remained until today without any validation. Later on,

${ }^{*}$ Corresponding author.

How to cite this paper: Öterler, B., Kirgiz, T. and Albay, M. (2014) Seasonal Variations of Water Quality Parameters and Algal Flora of Tundzha (Tunca) River (Edirne, Turkey). Open Journal of Ecology, 4, 807-819. 
Welch reported that the phytoplankton assemblages in rivers were much modified with respect to lakes [5].

Streams and rivers provide habitats which are very different from those in lakes, for they are subject to changes along their length associated with depth, rate of flow, geology of the land surface and of the stream bed, salt concentration, turbidity, etc., all these being further complicated by seasonal changes [6]. Phytoplanktons are un- able to maintain populations in fast-flowing streams, but can become abundant in slowly moving rivers and backwaters where their doubling rates exceed downstream loses due to current [7]. River and lake phytoplankton are subject to different factors. For instance, phytoplankton load in lakes is subject to nutrient load in deep lakes but in shallow lakes, stochastic meteorological events are of major importance. On the other hand, riverine phytoplankton are mainly related to light availability and time of travel instead of nutrient load [8].

Although studies on potamoplankton dated back to late 1890s, studies in Turkey started by the mid 1980s [9]-[11]. There are some early studies on segment of Tunca River in Bulgaria [12] [13], but no algological study has been performed so far within the Turkey. Part of the river forms meanders with a slow water current in a wider river bed.

We aim in this study i) to determine the composition, biomass and diversity of algal flora of Tunca River in Turkish Thrace, ii) to reveal longitudinal distribution patterns of present taxa along the river, and iii) to determine physicochemical factors affecting the algal composition of the river.

\section{Material and Methods}

\subsection{Study Area}

Tundzha (Tunca) River is the biggest segment of Maritza River who reaches Aegean Sea at Saros Bay which is classified as B class wetland according to Ramsar Pact. The river enters Turkey in Suakacağı Village of Lalapaşa-Edirne, after travelling about $350 \mathrm{~km}$ throughout Bulgarian land. The length of Turkey segment of the river is $54.7 \mathrm{~km}$ and the mean flow rate is $18.38 \mathrm{~m}^{3} / \mathrm{sec}$. The river meets with Maritza River to the south of Edirne city centre. The areas surrounding the river, as in Thrace region in general are used for corn, sun flower, crop, fruit, vegetable and particularly rice cultivation. Local woodland and scrubby areas along the river also exist. A preliminary study was performed and 5 stations were determined to represent the part of the river in Turkey from the Bulgarian border until it meets Maritza River (Figure 1). Water and phytoplankton samples were taken from the 5 stations twice a week from June 2002 to October 2003 and once a month from November 2002 to May 2003.

\subsection{Sampling}

A Ruttner water sampler was used to obtain water samples just below the surface of the water body in order to determine some physico-chemical properties of the river. Water temperature, Dissolved Oksigene, $\mathrm{pH}$ and con-

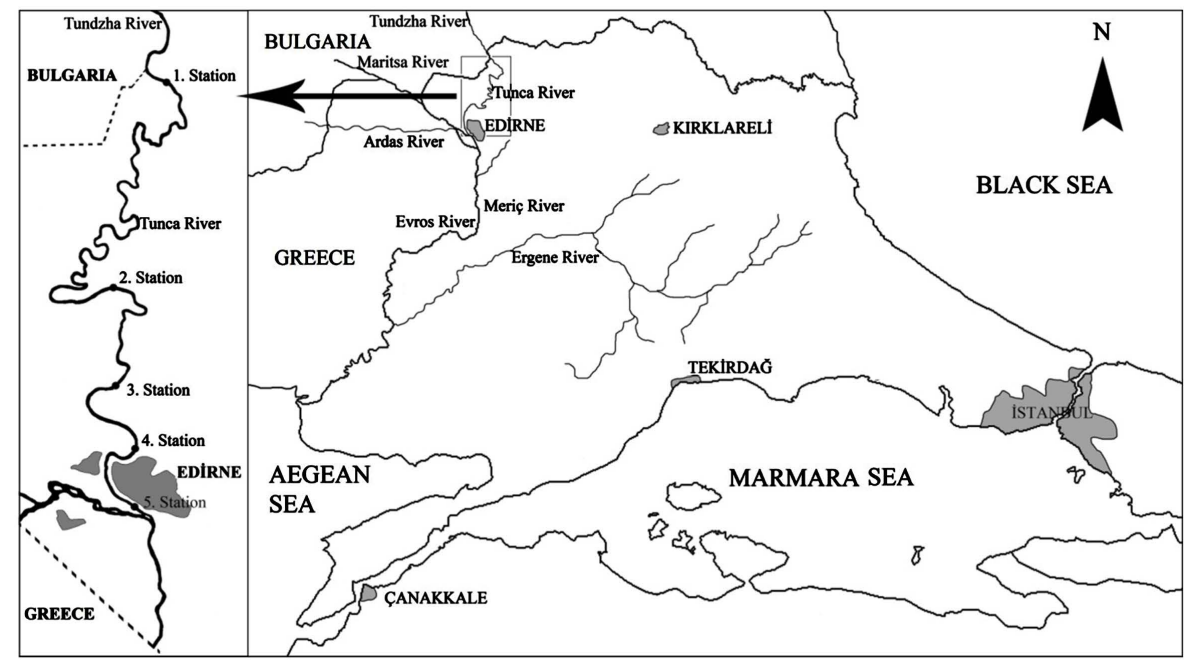

Figure 1. The map to Tundzha River and the stations selected along the study part of the river. 
ductivity were measured on site during samplings using field type equipments (Lovibond sensodirect oxi 200, pH 200 and Con 200) and $\mathrm{PO}_{4}-\mathrm{P}, \mathrm{NO}_{3}-\mathrm{N}, \mathrm{NO}_{2}-\mathrm{N}$, total hardness, $\mathrm{COD}$ and $\mathrm{BOD}$ were measured in laboratory in accordance with APHA-AWWA-WPCF methods [14]. Chlorophyll- $a$ was analyzed according to Nusch [15]. Winkler method was applied in dissolved oxygen determinations [16]. BOD and COD values were measured using methods given in Golterman [17].

Sampled phytoplankton specimens were identified by investigation of temporary preparations. For this purpose, water samples were filtered from Whatman GF/A ( $90 \mathrm{~mm}$ diam., $1.6 \mu \mathrm{m}$ pore size) paper with the help of a water trompe and dissolved in $10 \%$ glycerine. An Uthermol counting chamber was used to calculate the organism number per liter [18] [19]. Biovolumes were measured using geometric or combined forms formulae according to Standard Operating Procedure for Phytoplankton Analysis [20]. For the identification of algal species Husted, Cleve-Euler, Pestalozzi, Prescott, Komarek and Fott, Krammer and Lange-Bertalot were used [21][29]. And also all the species are checked in algaebase cite [30].

\subsection{Statistical Analysis}

A Bray-Curtis analysis was performed to reveal similarities, if any, among stations based on algal species diversity and abundance [31]. Abiotic variables were correlated with main phytoplankton attributes using non-parametric Spearman's correlation coefficients. Differences in all variables were tested using a non-parametric Kruskal-Wallis ANOVA median test (KW). Differences at the $<0.05$ level were accepted as significant. Also, to compare stations, non-parametric statistics (the Mann-Whitney U test) were used. Species richness was considered to be the number of taxa present in each sample. Biological diversity $\left(\mathrm{H}^{\prime}\right)$ was calculated by the Shannon and Weaver [32].

\section{Results}

\subsection{Water Quality Parameters}

The results of Physico-chemical analysis showed that the highest $\mathrm{pH}$ and dissolved oxygen values were measured in Station 1 in spring and winter months, respectively. The $\mathrm{Cl}$ content appeared to be high in station III in spring and Biological Oxygen Demand in station V in winter. Station V was also characterized with the highest Phosphate value in summer months. $\mathrm{NO}_{2}-\mathrm{N}$ and $\mathrm{NO}_{3}-\mathrm{N}$ was measured at high levels in stations III (in auntumn), respectively. The results also revealed that Chlorphyll_a was measured in its highest value in station IV in summer. The mean results of all analyis are given in Table 1.

Nitrate-N was found to be negatively correlated with water temperature, electrical conductivity and biomass and no significant relation was found between other physico-chemical variables $(\mathrm{P}<0.05)$. The comparison of stations based on abiotic factors revealed that all stations were similar $(\mathrm{P}<0.01)$.

\subsection{Phytoplankton Species Diversity}

The taxonomic evaluation of all samples obtained showed that a total of 138 taxa lived in the river (Table 2). Station I was the richest in terms of species diversity with 118 taxa while station 5 was the least diverse station with 87 taxa (Table 3). Chlorophyceae was found to be represented with the highest number of species (65 taxa) followed by Bacillariophyceae (46 taxa), Euglenophyta (13 taxa) and Cyanophyta and Charophyta (7 taxa). Since none of the 7 taxa of cyanophytes showed an extreme growth during the study period, they never were among the dominating or subdominating taxa and thus did not lead to formation of water bloom.

Chlorophyta, which was represented with 57 taxa in station I (richest) and 39 taxa in station V (poorest), appeared to be the dominant group in the phytoplankton community in the river. On the other hand, diatoms constituted the second dominant group and all stations were similar in terms of their diatom compositions. Although pennant diatoms were rich in terms of species diversity, Cyclotella species of centric diatoms were found to have the highest cell counts in all stations, particularly in spring, summer and autumn months.

\subsection{Abundance and Volume Biomass}

The highest cell counts were obtained in the sample from 1 th station $\left(3,459,313 \mathrm{cells} \cdot \mathrm{L}^{-1}\right)$ whereas the lowest counts were obtained from samples of 2 th $\left(1,713,312\right.$ cells $\left.\cdot \mathrm{L}^{-1}\right)$ and 5 th stations $\left(1,815,672 \mathrm{cells} \cdot \mathrm{L}^{-1}\right)$. Centric diatoms were highly abundant in the samples from the river (Figure 2). Cyclotella species, in particular, were 


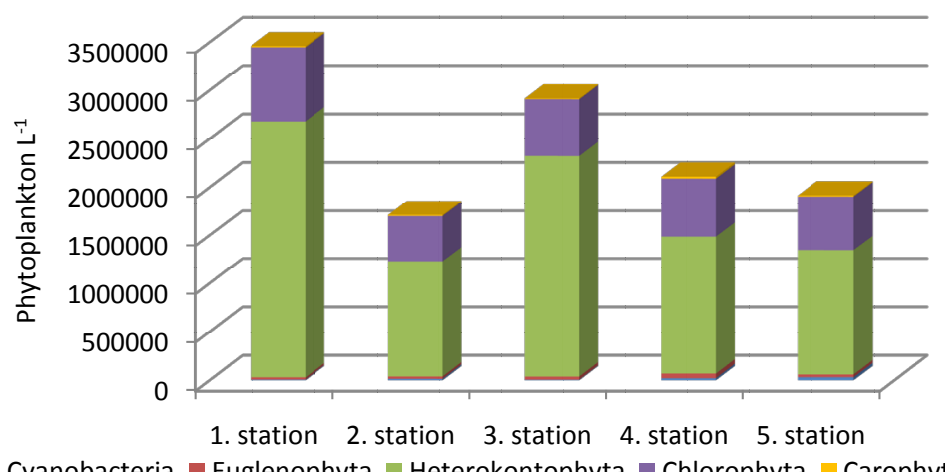

n Cyanobacteria $\square$ Euglenophyta $\square$ Heterokontophyta $\square$ Chlorophyta $\square$ Carophyta

Figure 2. The number of planktonic algal counts with respect to stations.

Table 1. The mean values of some Physico-chemical parameters in Tundzha River.

\begin{tabular}{|c|c|c|c|c|c|c|c|c|c|c|c|c|c|}
\hline & & $\begin{array}{c}\text { Water } \\
\text { Temperature } \\
\left({ }^{\circ} \mathrm{C}\right)\end{array}$ & $\begin{array}{l}\text { Conductivity } \\
(\mu \mathrm{mho} / \mathrm{cm})\end{array}$ & $\mathrm{pH}$ & $\begin{array}{l}\text { Diss. } \\
\text { Oxygen } \\
(\mathrm{mg} / 1)\end{array}$ & $\begin{array}{l}\text { Hardness } \\
(\cdot \mathrm{FS})\end{array}$ & $\begin{array}{l}\mathrm{NO}_{3}-\mathrm{N} \\
(\mathrm{mg} / \mathrm{l})\end{array}$ & $\begin{array}{l}\mathrm{NO}_{2}-\mathrm{N} \\
(\mathrm{mg} / \mathrm{l})\end{array}$ & $\begin{array}{l}\text { Sulphate } \\
(\mathrm{mg} / \mathrm{l})\end{array}$ & $\begin{array}{l}\text { Phosphate } \\
(\mathrm{mg} / \mathrm{l})\end{array}$ & BOD & C.O.D & $\begin{array}{l}\text { Chloro- } \\
\text { phyll_a }\end{array}$ \\
\hline \multirow{5}{*}{$\vec{E}$} & Ith Station & 24.17 & 0.65 & 8.59 & 8.25 & 40.53 & 2.13 & 0.00 & 2.42 & 0.11 & 2.72 & 21.17 & 64.97 \\
\hline & IIth Station & 24.42 & 0.77 & 8.25 & 9.97 & 44.30 & 1.50 & 0.01 & 2.78 & 0.06 & 2.45 & 10.83 & 21.66 \\
\hline & IIIth Station & 24.25 & 0.80 & 8.22 & 8.15 & 47.67 & 2.55 & 0.02 & 2.96 & 0.08 & 3.34 & 12.00 & 74.00 \\
\hline & IVth Station & 25.08 & 0.81 & 8.29 & 9.14 & 49.27 & 2.94 & 0.09 & 3.02 & 0.17 & 4.92 & 18.67 & 113.74 \\
\hline & Vth Station & 26.08 & 0.79 & 8.46 & 8.74 & 49.38 & 3.60 & 0.30 & 2.99 & 0.18 & 3.30 & 24.00 & 85.25 \\
\hline \multirow{5}{*}{ 䒠 } & Ith Station & 14.00 & 0.52 & 8.22 & 10.68 & 28.80 & 11.41 & 0.10 & 2.29 & 0.13 & 6.05 & 30.00 & 17.76 \\
\hline & IIth Station & 15.00 & 0.56 & 8.08 & 9.97 & 30.88 & 9.24 & 0.08 & 2.49 & 0.13 & 5.69 & 22.60 & 17.02 \\
\hline & IIIth Station & 15.50 & 0.58 & 8.12 & 10.25 & 30.36 & 11.73 & 0.10 & 2.51 & 0.13 & 5.45 & 24.40 & 12.43 \\
\hline & IVth Station & 15.80 & 0.58 & 8.11 & 9.44 & 30.08 & 11.42 & 0.16 & 2.55 & 0.15 & 4.54 & 24.20 & 12.65 \\
\hline & Vth Station & 16.10 & 0.61 & 8.03 & 9.20 & 29.92 & 10.84 & 0.15 & 2.51 & 0.15 & 3.54 & 25.40 & 13.09 \\
\hline \multirow{5}{*}{ 离 } & Ith Station & 4.33 & 0.42 & 8.32 & 13.58 & 27.33 & 9.00 & 0.05 & 2.31 & 0.06 & 3.73 & 23.33 & 4.59 \\
\hline & IIth Station & 4.00 & 0.42 & 8.37 & 11.23 & 26.33 & 6.86 & 0.06 & 2.18 & 0.06 & 4.43 & 36.33 & 5.18 \\
\hline & IIIth Station & 4.50 & 0.42 & 8.39 & 11.29 & 26.80 & 8.56 & 0.07 & 2.35 & 0.06 & 5.27 & 26.33 & 3.99 \\
\hline & IVth Station & 4.00 & 0.42 & 8.40 & 11.29 & 26.67 & 8.15 & 0.07 & 2.40 & 0.07 & 6.03 & 38.00 & 2.96 \\
\hline & Vth Station & 4.17 & 0.40 & 8.40 & 11.66 & 27.13 & 7.09 & 0.03 & 2.39 & 0.07 & 6.20 & 27.33 & 3.41 \\
\hline \multirow{5}{*}{ 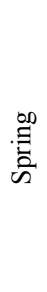 } & Ith Station & 11.17 & 0.58 & 8.64 & 12.12 & 33.93 & 9.18 & 0.08 & 3.44 & 0.07 & 4.50 & 38.33 & 10.85 \\
\hline & IIth Station & 11.67 & 0.57 & 8.68 & 7.96 & 33.00 & 7.34 & 0.04 & 3.18 & 0.05 & 3.95 & 37.67 & 11.43 \\
\hline & IIIth Station & 11.17 & 0.57 & 8.68 & 7.96 & 32.33 & 8.93 & 0.04 & 3.27 & 0.05 & 5.43 & 43.00 & 12.23 \\
\hline & IVth Station & 11.50 & 0.57 & 8.65 & 7.45 & 31.93 & 9.78 & 0.04 & 3.24 & 0.05 & 6.05 & 39.67 & 12.75 \\
\hline & Vth Station & 11.67 & 0.58 & 8.66 & 7.20 & 32.93 & 8.96 & 0.02 & 3.26 & 0.06 & 5.56 & 33.67 & 11.97 \\
\hline
\end{tabular}

obtained with high biomass values in all stations by the beginning of spring season. Diatoms appeared to be the dominant group in terms of cell counts followed by green algae as the second dominant group in the river. Other algal groups were recorded with low abundance values (Table 4). Most of the algal species found in the Bulgarian segment of the river were also determined in the present study except Ceratium, Peidinium, Dinobriyon and Stephanodiscus [13]. 
Table 2. The list of the planktonic algal species obtained in Tundzha River during the study period.

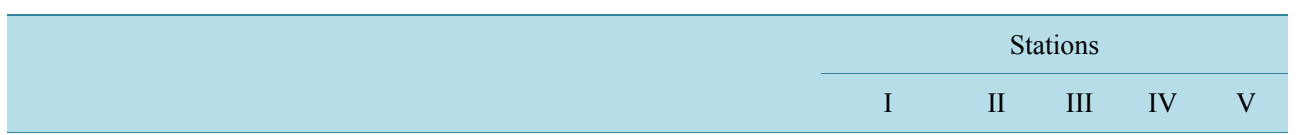

Empire Prokaryota

Kingdom Eubacteria

Subkingdom Negibacteria

Phylum Cyanobacteria

Class Cyanophyceae

Anabaena sp.

Aphanizamenon sp.

Merismopedia sp.

Microcystis sp.

Oscillatoria limosa Agardh

O. articulata Gardner

Oscillatoria sp.

Empire Eukaryota

Kingdom Protozoa

Phylum Euglenophyta

Class Euglenophyceae

Euglena acus (O. F. Müller) Ehrenberg

E. elongate Schewiakoff

E. gibbosa Schiller

E. limnophila Lemmermann

E. polymorpha P. A. Dangeard

E. tuberculata Swirenko

E. viridis (O.F.Müller) Ehrenberg

Phacus acuminatus Stokes

P. helikoides Pochmann

P. longicauda (Ehrenberg) Dujardin

$P$. orbicularis K. Hübner

P. tortus (Lemmermann) Skvortzov

Trachelomonas sp.

Empire Eukaryota

Kingdom Chromista

Phylum Heterokontophyta

Class Bacillariophyceae

Cocconeis placentula Ehrenberg

Gomphonema truncatum Ehren.

Cymbella cistula (Ehren.) Kirchner

C. tumida (Brébisson) van Heurck

$\begin{array}{ccccc}+ & + & + & + & + \\ + & + & + & + & + \\ + & + & + & + & + \\ + & + & + & + & +\end{array}$




\section{Continued}

Rhoicosphenia curvata (Kützing) Grun.

Class Fragilariophyceae

Asterionella formosa Hassall

Fragilaria crotonensis Kitton

Fragilaria virescens Ralfs

Diatoma vulgaris Bory de Saint-Vincent

Ulnariaacus (Kütz.) Cambra \& Ector

Ulnaria ulna (Nitzsch) P. Compère

Caloneis amphisbaena Cleve

Gyrosigma acuminatum (Kützing) Rab.

G. attenuatum (Kützing) Cleve

G. macrum (Smith) Cleve

Navicula Ehrenberg

$N$. cuspidate Kützing

$N$. virudula Kützing

N. expansa Hagelstein

$$
\text { Navicula sp. }
$$

Neidium affine (Ehrenberg) Pfizer

Pinnularia acuminata Smith

P. viridis Ehrenberg

Amphora ovalis Kützing

Hantzschia amphioxys Cleve \& Grun.

Nitzchia acicularis (Kützing) Smith

N. amphibian Grun.

N. flexa Schumann

N. elongate Hassal

$N$. palea (Kützing) W. Smith

N. parvula W. Smith

N. sigmoideae W. Smith

$N$. hungarica Grun.

$N$. obtuse Smith

Nitzchia sp.

Epithemia adnata (Kützing) Ross

Epithemia sorex Kützing

Mastogloia smithii Thwaites

Cymatopleura elliptica Smith

C. solea W. Smith

Surirella robusta Ehrenberg

S. ovalis Brébisson

Class Coscinodiscophyceae

Melosira varians Agardh

Aulacoseira italica (Ehrenberg) Simonsen

Class Mediophyceae 


\section{Continued}

Cyclotella meneghiniana Kütz.

Cyclotella sp.

Empire Eukaryota

Kingdom Plantae

Phylum Chlorophyta

Class Chlorophyceae

Pandorina morum (O. F. Müller) Bory

Class Trebouxiophyceae

Actinastrum hantzchii Lagerheim

Chlorella elipsoidea Gerneck

C. mirabilis Andreyeva

C. oocystidoides Hindak

C. vulgaris Beyerinck

Crucigeniella saugeii Komárek

C. rectangularis (Nägeli) Komárek

Crucigenia tetrapedia Kuntze

Golenkiniopsis longisipina Korshikov

Keratococcusbicaudatus Petersen

Lagerheimiagenevensis Chod.

L. wratislaviensis Schröder

Oocystis apiculata West

O. marssonii Lemmermann

O. parva West

Oocystis sp.

Dictyosphaerium sp.

Tetrachlorella incerta Hindák

Closteriopsis longissima Lemm.

Chlorobion brauni (Nägeli) Komárek

Coelastrum astroideum De Notaris

C. microporum Nägeli

C. morus $\mathrm{W} \& \mathrm{G}$ West

Golenkinia radiata Chod.

Pediastrum boryanum Meneghini

$$
\begin{aligned}
& \text { P. duplex Meyen } \\
& P \text {. simplex Meyen }
\end{aligned}
$$

P. tetras (Ehrenberg) Ralfs

Tetradesmus major Fott \& Komárek

Ankistrodesmus bibrainus Korshikov

Korshikoviella gracileps Silva

Kirchneriella aperta Teiling

K. lunaris (Kirchner) K. Möbius 


\section{Continued}

K. contorta (Schmidle) Bohlin

Kirchneriella sp.

Monoraphidium arcuatum (Korsh.) Hindák

M. contortum Kom-Legn

M. griffithii Kom-Legn

M. minitum Kom-Leg

Scenedesmusacuminatus (Lager.) Chod.

S. acutus Meyen

S. armatus Chodat

S. bicaudatus Dedusenko

S. disciformis Fott \& Komárek

S. ecornis Chod.

S. intermedius Chod

S. magnus Meyen

S. opolinensis Richter

S. pecsensis Dherk

S. protuberans Fritsch \& Rich

S. quadricauda (Turpin) Brébisson

S. quadrispina Chod.

S. spinosus Chod.

Schroederia antillarum Komárek

S. robusta Korshikov

Tetrastrum staugeniforme (Sch.) Lemm.

T. komarekii Hindák 1977

T. triangulare (Chodat) Komárek

Tetraedron minimum Hansgirg

T. caudatum Hansgirg

T. regulare Kützing

T. triangulare Korshikov

T. trigonum Hansgirg

Tetradesmus wisconsinensis Smith

Phylum Charophyta

Class Conjugatophyceae

Closterium acutum Brébisson

Closterium lunula Ehren. \& Hemp.

Closterium parvulum Nägeli

Cosmarium undulatum Corda

Cosmarium sp.

Staurastrum anatinum Cook \& Wills

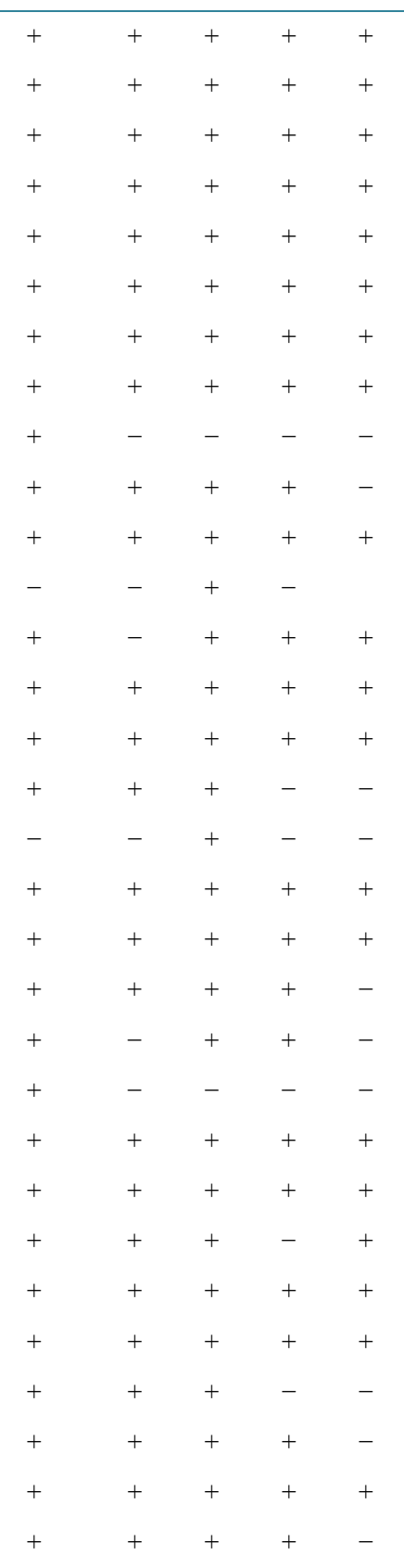

$\begin{array}{ccccc}+ & + & + & + & + \\ + & + & + & + & + \\ + & + & + & - & - \\ + & + & + & + & - \\ + & + & + & + & - \\ + & - & - & - & - \\ + & + & + & - & -\end{array}$ 
Table 3. Number of species and relative number of species [\%] determined in the plankton of the Tundzha River.

\begin{tabular}{|c|c|c|c|c|c|c|c|c|c|c|}
\hline \multirow{2}{*}{ Groups/Stations } & \multicolumn{2}{|c|}{ I. Station } & \multicolumn{2}{|c|}{ II. Station } & \multicolumn{2}{|c|}{ III. Station } & \multicolumn{2}{|c|}{ IV. Station } & \multicolumn{2}{|c|}{ V. Station } \\
\hline & $\Sigma$ taxa & $\%$ & $\Sigma$ taxa & $\%$ & $\Sigma$ taxa & $\%$ & $\Sigma$ taxa & $\%$ & $\Sigma$ taxa & $\%$ \\
\hline Cyanophyceae & 6 & 5.1 & 5 & 4.7 & 6 & 5.5 & 4 & 4.0 & 3 & 3.4 \\
\hline Euglenophyceae & 7 & 5.9 & 4 & 3.8 & 4 & 3.6 & 6 & 6.1 & 2 & 2.3 \\
\hline [Diatoms] & [41] & [34.7] & {$[43]$} & {$[40.6]$} & {$[43]$} & [39.1] & {$[41]$} & {$[41.4]$} & {$[41]$} & {$[47.1]$} \\
\hline Bacillariophyceae & 5 & 4.2 & 5 & 4.7 & 5 & 4.5 & 5 & 5.1 & 5 & 5.7 \\
\hline Fragilarophyceae & 32 & 27.1 & 34 & 32.1 & 34 & 30.9 & 32 & 32.3 & 32 & 36.8 \\
\hline Coscinodiscophyceae & 2 & 1.7 & 2 & 1.9 & 2 & 1.8 & 2 & 2.0 & 2 & 2.3 \\
\hline Mediophyceae & 2 & 1.7 & 2 & 1.9 & 2 & 1.8 & 2 & 2.0 & 2 & 2.3 \\
\hline Chlorophyta & 57 & 48.3 & 48 & 45.3 & 51 & 46.4 & 44 & 44.4 & 39 & 44.8 \\
\hline Conjugatophyceae & 7 & 5.9 & 6 & 5.7 & 6 & 5.5 & 4 & 4.0 & 2 & 2.3 \\
\hline$\Sigma[138$ taxa $]$ & 118 & 100 & 106 & 100 & 110 & 100 & 99 & 100 & 87 & 100 \\
\hline
\end{tabular}

Table 4. Planktonic cell counts and biomass in Tundzha River.

\begin{tabular}{ccccc}
\hline \multirow{2}{*}{ Groups } & \multicolumn{2}{c}{ Cells } & \multicolumn{2}{c}{ Biomass } \\
\cline { 2 - 5 } & Per L & $\%$ & $\mathrm{~g} \cdot \mathrm{L}^{-1}$ & $\%$ \\
\hline Cyanophyceae & 50,879 & 2.1 & 74.9 & 4.5 \\
Euglenophyceae & 79,953 & 3.3 & 135.8 & 8.2 \\
[Diatoms] & {$[1,693,548]$} & {$[69.9]$} & {$[835.9]$} & {$[50.3]$} \\
Bacillariophyceae & 21,805 & 0.9 & 15.4 & 0.9 \\
Fragilarophyceae & 237,436 & 9.8 & 277.1 & 16.7 \\
Coscinodiscophyceae & 67,839 & 2.8 & 226.1 & 13.6 \\
Mediophyceae & $1,366,468$ & 56.4 & 317.3 & 19.1 \\
Chlorophyta & 562,093 & 23.2 & 605.0 & 36.4 \\
Conjugatophyceae & 36,342 & 1.5 & 11.4 & 0.7 \\
$\Sigma$ & $2,422,816$ & 100 & 1663 & 100 \\
\hline
\end{tabular}

Differences in the biovolume of phytoplankton from the 5 sampling sites are illustrated in Figure 3. Diatoms are the prevailing group in samples from all localities except the 4th station where Chlorophyta was the dominant group. The biovolume of Euglenophyta members were measured to be highest in the 4th station (2028.8 $\left.\mu \mathrm{g} \cdot \mathrm{L}^{-1}\right)$ whereas it was the lowest in the 5 th station $\left(1366.8 \mu \mathrm{g} \cdot \mathrm{L}^{-1}\right)$.

When floristic compositions of all 5 stations were used to obtain a similarity index through the cluster analysis, the 2th and 3rd stations were found to have very similar floristic compositions and, although all stations revealed a somewhat same similarity, the 5th station was grouped to be the outgroup among the stations with the least similarity (Figure 4(a)). The cluster analysis based on biovolumes measured for each stations revealed that the 1th and 3th stations were the most similar ones to each other (Figure 4(b)).

The abundance of phytoplankton was significant, and was positively correlated with Chl-a and temperature ( $\mathrm{r}$ $=0.77$ and $\mathrm{r}=0.86$, respectively $\mathrm{P}<0.01$ ). The biovolume of Bacillariophyta was positively correlated with the species number $(\mathrm{r}=0.71, \mathrm{P}<0.01)$. The estimates of algal biomass did not show any correlation with nutrients. Some water quality parameters were found to show a significant relationship with the dominant taxa. For example, DO concentration was correlated with the mean total number of C. meneghiniana and M. varians $(r=0.72$ 


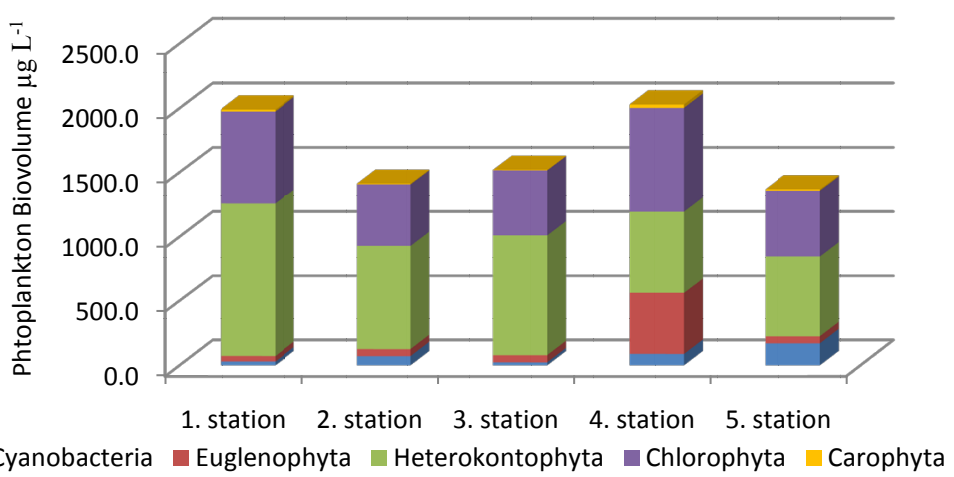

Figure 3. Biovolume of phytoplankton (per Liter) of sampling sites.

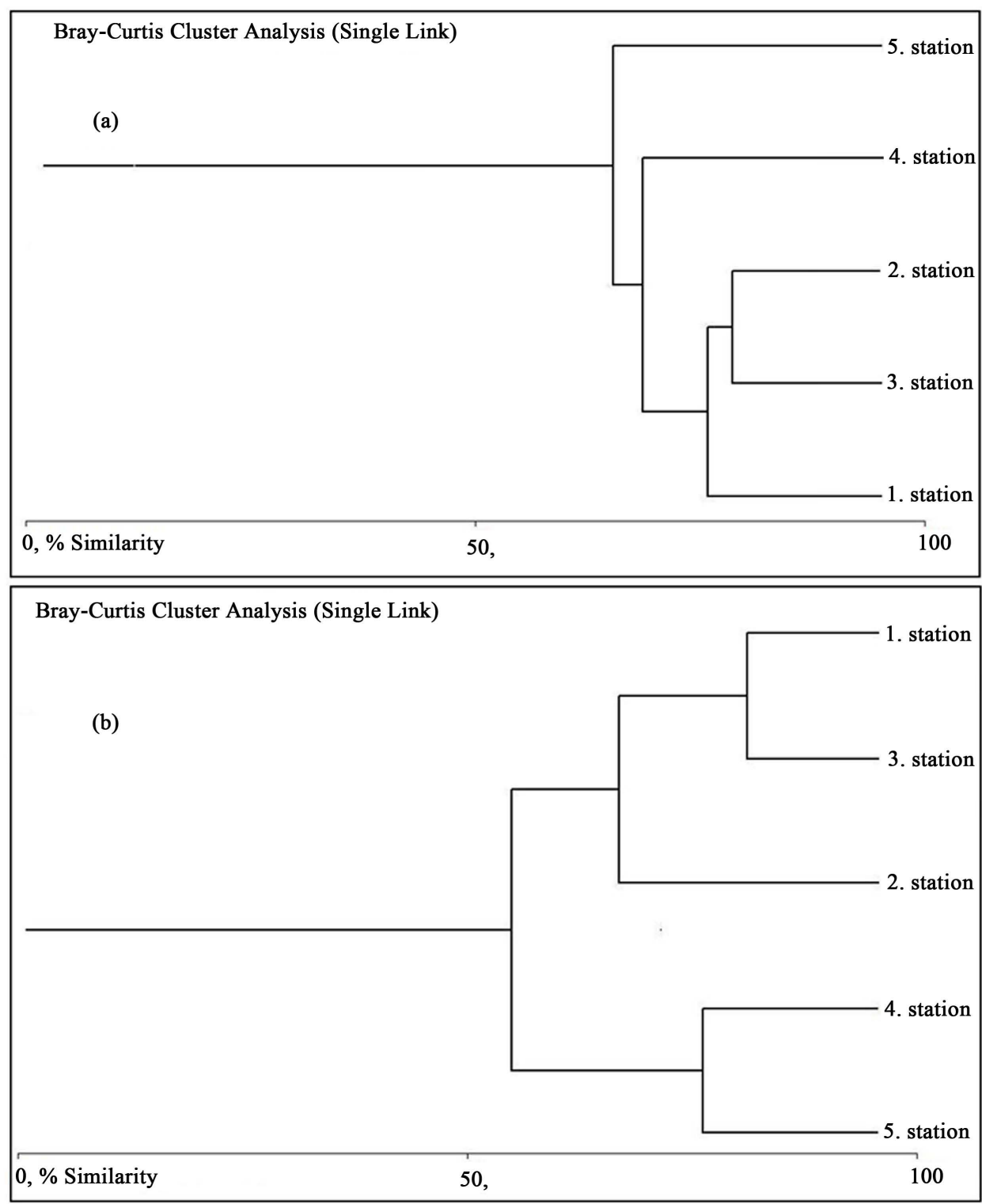

Figure 4. Results of clustering analyses: (a) based on differences in the floristic composition of phytoplankton (Bray-Curtis distance); (b) based on differences in portions of main distinguished algal groups (Bray-Curtis distance). 
and $\mathrm{r}=0.61$, respectively $\mathrm{P}<0.05$ ). In addition, nitrate and phosphate were found to negatively correlated with biovolume $(\mathrm{r}=-0.71$ and $\mathrm{r}=-0.54$, respectively $\mathrm{P}<0.05)$.

\section{Conclusions}

It is well known that oxygen is consumed during decomposition of organic materials in waters and regain of the consumed oxygen is rather slow in surface waters [33]-[35], which is a fact naturally affecting organisms living here. The low productivity values measured in the 4th and 5th stations were concluded to be related with this pollution. The low $\mathrm{NO}_{3}-\mathrm{N}$ values, despite the high measured nitrite, showed that nitrification process did not take place as a result of low oxygen values. The water quality of the river was found to be ranked in the II and III class according to the criteria of SKKY [36].

The plankton surveys in the river allowed us to provide a list of up to 136 taxa, which were of cosmopolitan distribution, characteristic for mesotrophic or eutrophic running waters. But the list of common and truly planktonic taxa is much less and few because the actual number of any planktonic taxa specific to river is low. The periodicity of phytoplankton the Tundzha River was influenced by complex interactions among allogenic and autogenic factors. Chlorophyta was the dominant group in the river throughout the study period in terms of species diversity and diatoms were the leading group in terms of biovolume.

In most large rivers, Bacillariophyceae blooms tend to occur in spring and fall, whereas a mixture of Chlorococcales and Bacillariophyceae appears during summer [37] [38]. The present Cyclotella bloom observed in Tundzha River from mid spring to mid autumn is a common phenomenon in other eutrophicated rivers as well. The varying abundances of these taxa in Tundzhariver in different seasons fit the classification of Descy (1987) in European rivers who reported that centric diatoms were dominant and green algae were abundant in summer in slow-moving, nutrient-rich large rivers.

Organisms with low tolerance to organic pollution, i.e. Nitzchiapalea (Kütz.) Smith, were determined in the river. In addition to Cyclotellameneghiniana (Kütz.), an indicator of mesotrophic waters, polluted water adapted organisms, Rhoicospheniacurvata (Kütz.) Grun. and Cocconeisplacentula (Ehr.) Cleve, preferring eutrophic water bodies were also found [39]. Naviculavirudula Kütz., an algal species preferring eutrophic lowland rivers is another tax a frequently determined during the study [40]. The representatives of Euglena, Navicula, Oscillatoria and Ulnaria found in the river are high tolerant species to pollution as reported by Şen [41]. The varying abundances of algal taxa in polluted sites are considered as indication of pollution here. The results revealed that species diversity of the genera within Euglenophyta showed an increase in the 4th station particularly in summer months as a result of increase in discharge of organic material originating from Edirne city centre accompanied with increased evaporation and agricultural water use. Moreover, Chlorphyll_a content of this part of the river was also found to increase significantly.

When the phytoplankton biomass reached its maximum values, namely in summer season, Chlorphyll_a also exhibited that it reached its maximum, in July and August. The high concentration of Chlorphyll_a indicated high productivity, also noted in numerical abundance and biomass of phytoplankton. It is now accepted that in any river or flowing water, the amount of plankton increases downstream. In the present investigation, during early months of winter, the plankton is found to be at its minimum. This supports the hypothesis of Schroder who stated that the volume of plankton present in any stream was inversely proportional to the rate of the water current [42].

Coinciding with what Claps [43] pointed out, a reduction in algal population after the spring floods could be seen. Planktonic algae flora of the Tundzha River were affected in the same way by flood in spring. Similar conditions were also observed in Yeşilırmak River, Euphrates (Karasu) River and Meram Stream [44]. However, floods affected communities in different ways in the River Pampean in Argentina [45] (Solari and Claps, 1996).

Although the present results cannot be used for a retrospective comparison of former and current aspects of the river to put forward whether the species number and biomass change in time or not because no similar study has been performed in the Turkey segment of the river, the results coincide with that of studies performed in Bulgaria.

\section{References}

[1] Hensen, V. (1887) Tiber Die Bestimmung des Planktons oder des im Meere treibenden Materials an Pflanzen und Tieren. Ber. der Komm. Wiss. Unters. Dt. Meere, 5, 1-109. 
[2] Zacharias, O. (1898) Das Potamoplankton. Zoologischer Anzeiger, 21, 41-48.

[3] Kofoid, C.A. (1903) The Plankton of the Illinois River, 1894-1899, with Introductory Notes upon the Hydrography of the Illinois River and Its Basin. Part I. Quantitative Investigations and General Result. Bulletin of the Illinois State Laboratory of Natural History, 6, 95-629.

[4] Butcher, R.W. (1924) The Plankton of the River Wharfe. Naturalist, 175-180, 211-214.

[5] Welch, P.S. (1952) Lymnology. McGraw-Hill Publication, New York, 538 p.

[6] Round, F.E. (1981) The Biology of the Algae. Edward Arnold Limited, London, 592 p.

[7] Allan, J.D. and Castillo, M.M. (2007) Stream Ecology: Structure and Function of Running Waters. 2nd Edition, Chapman and Hall, New York. http://dx.doi.org/10.1007/978-1-4020-5583-6

[8] Köhler, J. and Hoeg, S. (2000) Phytoplankton Selection in a River-Lake System during Two Decades of Changing Nutrient Supply. Hydrobiologia, 424, 3-24. http://dx.doi.org/10.1023/A:1003988508599

[9] Yıldız, K. (1984) Meram Çayı Alg Toplulukları Üzerindeki Araştırmalar. I. Fitoplankton Topluluğu. Sü Fen-Edebiyat Fak Fen Dergisi, 3, 213-217.

[10] Yıldız, K. (1984) Meram Çayı Alg Toplulukları Üzerinde Araştırmalar. II. Taş ve Çeşitli Bitkiler Üzerinde Yaşayan Alg Topluluğu. Sü Fen-Edebiyat Fak Fen Dergisi, 3, 218-222.

[11] Yıldız, K. (1985) Meram Çayı Alg Toplulukları Üzerinde Araştırmalar. III. Sedimanlar Üzerinde Yaşayan Algler. Doga Bilim Dergisi, 9, 428-434.

[12] Dimitrova, M. and Nikolova, M. (1968) Saprobiological Characteristics of the River Tundza. Hidrotechn, 13, $309-311$.

[13] Saiz, D. (1981) Phytoplankton Development in the Toundza River-Zhrebchevo Reservoir System. Hydrobiology, 15, 8-21.

[14] APHA-AWWA-WPCF (1992) Standard Methods for the Examination of Water and Waste Water. 18th Edition, American Water Works Association and Water Pollution Control Federation, Washington DC, 10-137.

[15] Nusch, E. (1980) Comparison of Different Methods for Chlorophyll and Phaeopigment Determination. Archiv für Hydrobiologie, 14, 14-36.

[16] Şengül, F. and Türkman, A. (1985) Su ve Atıksu Analizleri Laboratuar Notları. Dokuz Eylül Üniversitesi Mühendislik. Mimarlık Fakültesi Ders Notları Yayın No 2., Baskı İzmir.

[17] Golterman, H.L., Clymo, R.S. and Ohnstadt, M.A.M. (1978) Methods for Physical and Chemical Analysis of Freshwaters. 2nd Edition, Blackwell Scientific Publications, Oxford, Edinburgh, London, Melbourne.

[18] Utermöhl, H. (1958) Zur Ver vollkommung der quantitativen phytoplankton-methodik. Mitteilung Internationale Vereinigung Fuer Theoretische unde Amgewandte Limnologie, 9, 39 p.

[19] Round, F.E. (1973) The Biology of the Algae. 2nd Edition, Edward Arnold Publishers, London, 278 p.

[20] GLNPOs WQS. LG 401 (2007) Standard Operating for Phytoplankton Analysis. Revisions 04, 8-42.

[21] Husted, F. (1930) Bacillariophyta (Diyatomeee) Heft: 10 in a Pascher Die Susswasser Flora Mitteleuropas. Gustav Fischer Publication, Jena, 1-466.

[22] Cleve-Euler, A. (1952) Die Diatomen Von Schweden und Finnland Stockholm. Almquist und Wiksells Bactryckeri Ab., Stockholm, 1-153.

[23] Pestalozzi, H.G. (1955) Das Phytoplankton des Susswasser Teil: 4 E. Schweizerbart'sche Verlagsbuchhandlund (Nagele U. Obermiller), Stuttgart, 1-1135.

[24] Pestalozzi, H.G. (1982) Das Phytoplankton des Susswasser Teil: 8 E. Schweizerbart'sche Verlagsbuchhandlund (Nagele U. Obermiller), Stuttgart, 1-539.

[25] Prescott, G.W. (1973) Algae of Western Great Lake Area. Fifth Printing, William C. Brown Publishers, Dubuque, 1977.

[26] Komárek, J. and Fott, P. (1983) Chlorophyceae: Chlorococcales. Das Phytoplankton Des Süßwassers. 7. Teil, 1. Hälfte. Stuttgart.

[27] Krammer, K. and Lange-Bertalot, H. (1991) Süßwasserflora von Mitteleuropa. Bacillariophyceae, Band 2/3, 3. Teil: Centrales, Fragillariaceae, Eunoticeae. Gustav Fischer Verlag, Stuttgart, 1-576.

[28] Krammer, K. and Lange-Bertalot, H. (1991) Süßwasserflora von Mitteleuropa. Bacillariophyceae, Band 2/4, 4. Teil: Achnanthaceae. Kritische Ergänzungen zu Navicula (Lineolatae) und Gomphonema Gesamtliteraturverzeichnis. Gustav Fischer Verlag, Stuttgart, 1-436.

[29] Krammer, K. and Lange-Bertalot, H. (1999) Süßwasserflora von Mitteleuropa. Bacillariophyceae, Band 2/2, 2. Teil: Bacillariaceae, Epithemiaceae, Surirellaceae. Spectrum Academicher Verlag, Berlin, 1-610.

[30] Guiry, M.D., Rindi, F. and Guiry, G.M. (2010-2011) AlgaeBase: World-Wide Electronic Publication. National Univer- 
sity of Ireland, Galway. www.algaebase.org

[31] Bray, R.J. and Curtis, J.T. (1957) An Ordination of the Upland Forest Communities of Southern Wisconsin. Ecological Monographs, 27, 325-349. http://dx.doi.org/10.2307/1942268

[32] Shannon, C.E. and Weaver, W. (1963) The Mathematical Theory of Communication. Illinois University Press, Urbana.

[33] Reynolds, C.S. and Descy, J.P. (1996) The Production, Biomass and Structure of Phytoplankton in Large Rivers. Archiv für Hydrobiologie, 10, 161-187.

[34] Descy, J.P. (1987) Phytoplankton Composition and Dynamics in the River Meuse (Belgium). Archiv für Hydrobiologie, 78, 225-245.

[35] Tan, A. (2006) Atıksularda Bazı Kirlilik Parametrelerinin İncelenmesi (Yüksek Lisans Tezi). T.Ü. Fen Bilimleri Enstitüsü, Anorganik Kimya Anabilim Dalı, 85 p.

[36] SKKY (2004) Su Kirliliği Kontrol Yönetmeliği, Yayımlandı̆̆ı Resmi Gazete, 31 Aralık Cuma 2004, Sayı: 25687.

[37] Stoyneva, M.P. and Draganov, S.J. (1991) Green Algae in the Phytoplankton of the Danube (Bulgarian Sector) Species Composition, Cell Numbers and Biomass. Archiv für Protistenkunde, 139, 243-260. http://dx.doi.org/10.1016/S0003-9365(11)80023-0

[38] Gosselain, V., Descy, J.P. and Everberg, E. (1994) The Phytoplankton Community of the River Meuse, Belgium: Seasonal Dynamics (Year 1992) and the Possible İncidence of Zooplankton Grazing. Hydrobiologia, 289, 179-191. http://dx.doi.org/10.1007/BF00007419

[39] Van Dam, H., Mertens, A. and Sinkeldam, J. (1994) A Coded Check List and Ecological İndicator Values of Freshwater Diatoms and Ecological İndicator Values of Freshwater Diatoms from Netherland. Netherlands Journal of Aquatic Ecology, 28, 117-133. http://dx.doi.org/10.1007/BF02334251

[40] Hwang, S.-J., Kim, N.-Y., Yoon, S.A., Kim, B.-H., Park, M.H., You, K.-A., Lee, H.Y., Kim, H.S., Kim, Y.J., Lee, J., Lee, O.M., Shin, J.K., Lee, E.J., Jeon, S.L. and Joo, H.S. (2011) Distribution of Benthic Diatoms in Korean Rivers and Streams in Relation to Environmental Variables. Annales de Limnologie-International Journal of Limnology, 47, S15-S33. http://dx.doi.org/10.1051/limn/2011017

[41] Şen, B. and Nacar, V. (1988) Su Kirliliği ve Algler. Fırat Havzası Birinci Çevre Sempozyumu, 405-419.

[42] Schroder, B. (1897) Uber des plankton der oder. Berichte der Deutschen Botanischen Gesellschaft, 15, 482-492.

[43] Claps, C. (1996) Structure and Dynamics of Epipelic Algae from a Plain River (Samborombon River, Buenos Aires, Argentina). Archiv für Hydrobiologie, 137, 251-263.

[44] Soylu, E.N. and Gönülol, A. (2003) Phytoplankton and Seasonal Variations of the River Yesilırmak, Amasya, Turkey. Turkish Journal of Fisheries and Aquatic Sciences, 3, 17-24.

[45] Solari, L.C. and Claps, M.C. (1996) Planktonic and Benthic Algae of a Pampean River (Argentina): Comparative Analysis. Annales de Limnologie, 32, 89-95. http://dx.doi.org/10.1051/limn/1996011 
Scientific Research Publishing (SCIRP) is one of the largest Open Access journal publishers. It is currently publishing more than 200 open access, online, peer-reviewed journals covering a wide range of academic disciplines. SCIRP serves the worldwide academic communities and contributes to the progress and application of science with its publication.

Other selected journals from SCIRP are listed as below. Submit your manuscript to us via either submit@scirp.org or Online Submission Portal.
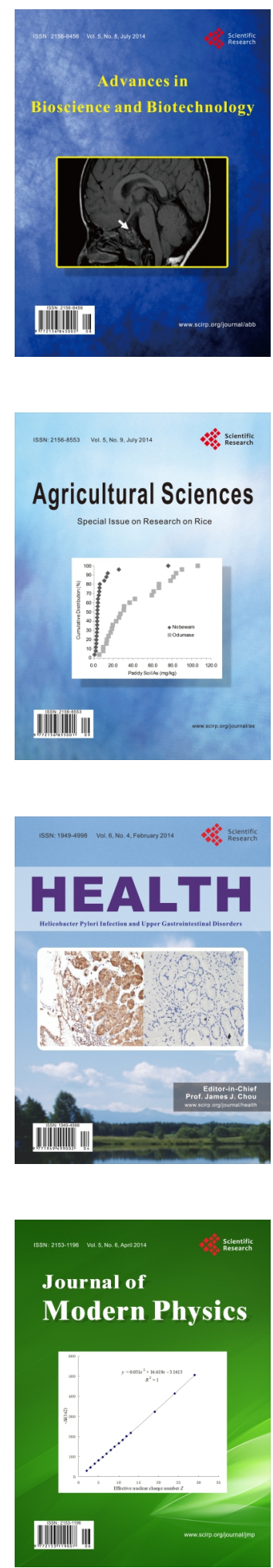
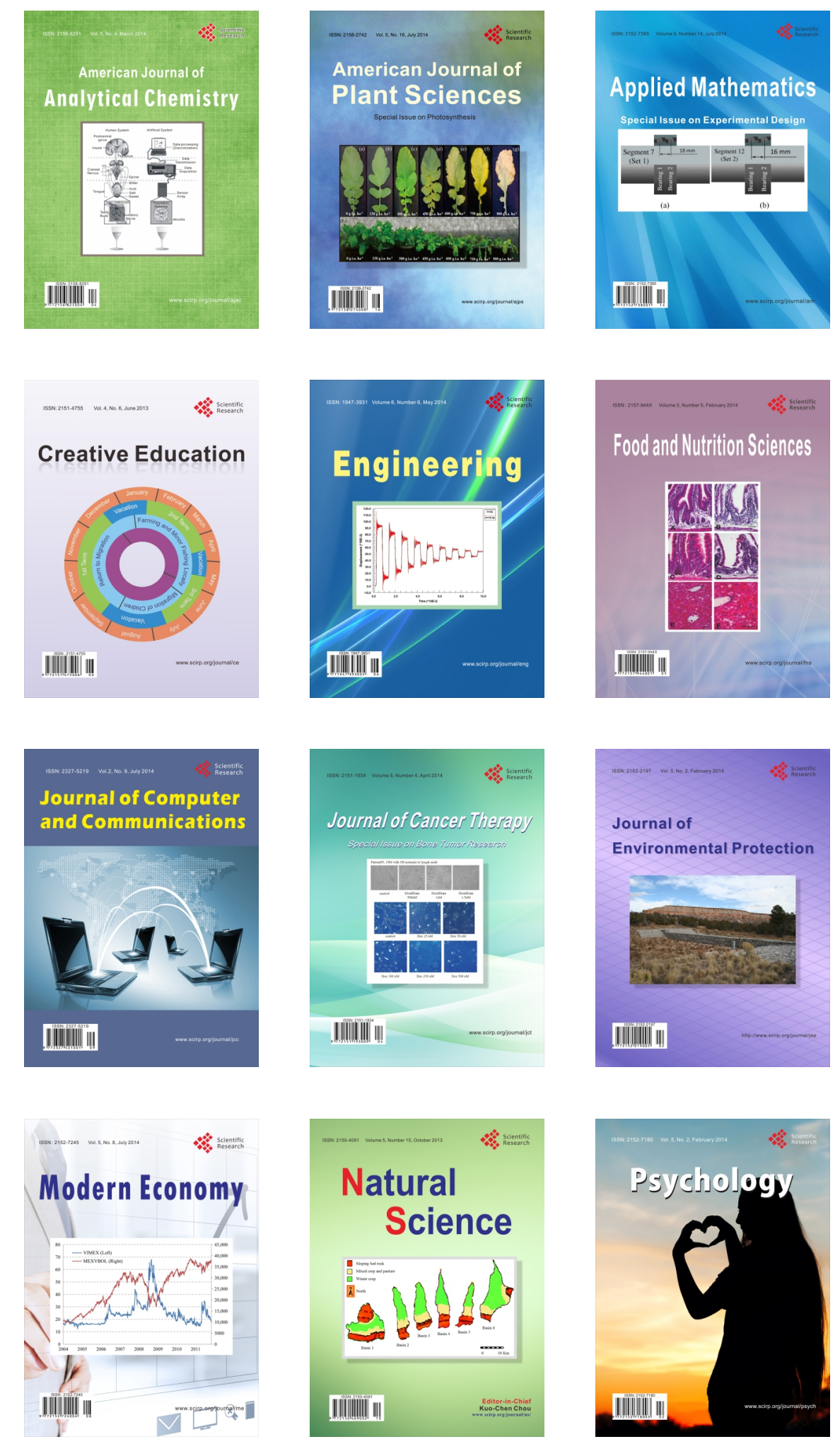